\title{
Elevated Blood Pressure Measurement
}

National Cancer Institute

\section{Source}

National Cancer Institute. Elevated Blood Pressure Measurement. NCI Thesaurus. Code C114798.

An abnormally high blood pressure reading. 